\title{
GAMBARAN MENGENAI METODE MENGAJAR SESUAI DAN TIDAK SESUAI DIKEMBANGKAN DALAM PROGRAM TK
}

\author{
Yenny \\ Fakultas Psikologi Universitas Mercu Buana \\ email: yenny.puc@gmail.com
}

\begin{abstract}
An Overview Of Teaching Methods Appropriate And Inappropriate In Developed In Kindergarten Program. With the increasing understanding of how young children develop and learn, there has been a greater emphasis on the education of young children. This study aims to obtain a description of appropriate and inappropriate teaching methods developed in a kindergarten program, specifically in the village of South Meruya. This research is qualitative descriptive, using interview method to teaching method of kindergarten teacher. The subjects consisted of 8 kindergarten teachers, consisting of 4 teachers of kindergarten and 4 teachers of kindergarten. The results obtained from this research are the kindergarten teachers in Meruya Selatan Village have shown appropriate teaching methods developed in the kindergarten program almost on all components except the teaching strategy component (addressing the ideas conveyed by the children), content and curriculum approach (aesthetic expression), reciprocal relationship with parents, and program policies (teacher-child ratio).
\end{abstract}

Key words: Teaching Method, Appropriate And Inappropriate, Kindergarten Program

\begin{abstract}
Abstrak : Gambaran Mengenai Metode Mengajar Sesuai Dan Tidak Sesuai Dikembangkan Dalam Program TK. Dengan meningkatnya pemahaman tentang bagaimana anak-anak kecil berkembang dan belajar, telah muncul penekanan yang lebih besar pada pendidikan anak-anak kecil. Penelitian ini bertujuan untuk memperoleh gambaran mengenai metode mengajar yang sesuai dan tidak sesuai dikembangkan dalam program taman kanak-kanak, secara khusus di kelurahan Meruya Selatan. Penelitian ini bersifat kualitatif deskriptif, dengan menggunakan metode wawancara terhadap metode mengajar guru taman kanak-kanak. Subjek penelitian ini terdiri dari 8 orang guru taman kanak-kanak, yang terdiri dari 4 orang guru TK-A dan 4 orang guru TK-B. Hasil yang diperoleh dari penelitian ini adalah guru taman kanak-kanak di Kelurahan Meruya Selatan sudah menunjukkan metode mengajar yang sesuai dikembangkan dalam program taman kanak-kanak hampir pada semua komponen kecuali komponen strategi pengajaran (menyikapi ide-ide yang disampaikan oleh anak-anak), isi dan pendekatan kurikulum (ekspresi estetika), hubungan timbal balik dengan orangtua, dan kebijakan program (rasio guru-anak).
\end{abstract}

Kata kunci : Metode Mengajar, Sesuai Dan Tidak Sesuai, Program Taman Kanak-Kanak 
Dengan meningkatnya pemahaman tentang bagaimana anak-anak kecil berkembang dan belajar, telah muncul penekanan yang lebih besar pada pendidikan anak-anak kecil. Masuk ke Taman Kanak-Kanak, dimulainya "Sekolah yang sebenarnya" adalah langkah yang penting, memperluas lingkungan fisik, kognitif, dan sosial anak.

Pada tahun 2001, sebanyak 64 persen anak usia 3-5 tahun didaftarkan ke prapendidikan primer dan pendidikan primer (Tujuh persen dari anak usia 5 tahun didaftarkan ke sekolah primer) dan tingkatnya lebih tinggi di banyak negara industri lain (Sen, Partelow, dan Miller, 2005).

Kemendikbud mewajibkan siswa mengikuti pendidikan anak usia dini (PAUD) yakni TK dan kelompok bermain, sebelum masuk SD. Alasannya, pembelajaran setahun sebelum SD diwajibkan oleh Badan urusan pendidikan di PBB; UNESCO (www.jpnn.com).

Sejumlah pakar dalam bidang pendidikan masa awal anak-anak percaya bahwa kurikulum di kebanyakan taman kanakkanak dan program-program prasekolah dewasa ini menaruh terlalu banyak penekanan pada prestasi dan keberhasilan. Hal itu menyebabkan anak-anak kecil itu mengalami tekanan yang terlalu dini dalam perkembangan mereka (Bredekamp \& Shepard, 1989; Bursts \& others, in press; Charlesworth, 1989; Elkind, 1987, 1988; Moyer, Egertson, \& Isenberg, 1987 dalam Santrock, 2002).

Pendukung pendekatan perkembangan tetap bertahan bahwa program yang berorientasi akademis mengabaikan kebutuhan anak kecil untuk mengeksplorasi dan bermain bebas serta instruksi yang terlalu banyak dari guru dapat menghambat minat mereka dan merusak pembelajaran atas inisiatif sendiri (Elkind, 1986; Zigler, 1987 dalam Papalia, 2009).
Bentuk Taman Kanak-Kanak seperti apa yang terbaik untuk anak? Di taman kanakkanak yang berpusat pada anak, (childcentered kindergarten) pendidikan melibatkan seluruh anak dan mencakup kepedulian akan perkembangan fisik, kognitif, dan sosial anak. Pembelajaran diorganisasikan sesuai dengan kebutuhan-kebutuhan, minat-minat dan gaya belajar anak. Penekanan adalah pada proses belajar dan bukan pada apa yang dipelajari.

Setiap anak mengikuti suatu pola perkembangan yang unik, dan anak-anak kecil paling baik belajar melalui pengalaman tangan pertama (langsung) dengan manusia dan benda-benda. Bermain sangat penting dalam perkembangan total anak. Mencoba, menjelajahi, menemukan, menguji-coba, menstrukturisasi, berbicara, dan mendengar ialah kata-kata yang menggambarkan programprogram taman kanak-kanak yang bagus. Program-program seperti itu terkait erat dengan status perkembangan anak-anak usia 4 dan 5 tahun. Program didasarkan atas suatu keadaan yang tengah berlangsung, bukan atas suatu keadaan yang akan jadi (Ballenger, 1983 dalam Santrock, 2002).

Sejumlah besar pendidik dan psikolog yakin bahwa anak-anak prasekolah dan sekolah dasar paling baik belajar melalui metode-metode mengajar yang aktif dan bersifat konkret seperti permainan dan bermain drama. Mereka tahu bahwa anak-anak berkembang pada berbagai tingkat dan bahwa sekolah harus diberi keleluasaan untuk bekerja berdasarkan perbedaan-perbedaan individual murid. Mereka juga yakin bahwa sekolah harus berfokus pada peningkatan perkembangan sosial anak-anak dan juga perkembangan kognitifnya. Para pendidik menyebut jenis persekolahan ini sebagai praktik yang cocok menurut teori perkembangan (developmentally appropriate practice), yang didasarkan atas pengetahuan tentang perkembangan umum anak dalam suatu rentang usia (kecocokan usia) dan juga keunikan anak (kecocokan individu). 
Praktik yang cocok berbeda dari praktik yang tidak cocok, yang mengabaikan pendekatan belajar yang bersifat konkret dan aktif. Pada umumnya pengajaran langsung melalui kegiatan yang bersifat abstrak dan melalui kertas-dan-pensil yang diberikan kepada sejumlah besar anak kecil diyakini sebagai praktik yang tidak cocok menurut teori perkembangan.

Salah satu dokumen yang paling komprehensif berbicara tentang isu metode mengajar yang sesuai dikembangkan pada program masa awal anak-anak ialah pernyataan sikap oleh NAEYC (National Association for the Education of Young Children, 1986; Bredekamp, 1987 dalam Santrock, 2002). Dokumen ini menyajikan pendapat dari banyak pakar terkenal di bidang pendidikan masa awal anak-anak.

1. Menciptakan komunitas yang peduli peserta didik.

a. Mempromosikan iklim yang positif untuk belajar.

b. Membina kelompok kohesif dan memenuhi kebutuhan individu.

2. Mengajar untuk meningkatkan pengembangan dan belajar.

a. Lingkungan dan jadwal.

b. Pengalaman belajar.

c. Bahasa dan komunikasi.

d. Strategi pengajaran.

e. Motivasi dan bimbingan.

3. Menyusun kurikulum yang sesuai.
a. Kurikulum terpadu.
b. Kontinum perkembangan dan pembelajaran.
c. Kurikulum yang koheren, efektif.
d. Isi dan pendekatan kurikulum.

4. Menilai pembelajaran dan perkembangan anak-anak.

5. Hubungan timbal balik dengan orangtua.

6. Kebijakan program.

Tujuan penelitian ini adalah untuk memperoleh gambaran mengenai metode mengajar yang sesuai dan tidak sesuai dikembangkan dalam program taman kanakkanak, secara khusus di kelurahan Meruya Selatan.

\section{METODE}

Penelitian ini merupakan penelitian kualitatif deskriptif, yang menggambarkan metode mengajar yang sesuai dan tidak sesuai dikembangkan dalam program taman kanakkanak, secara khusus di kelurahan Meruya Selatan. Pengumpulan data dilakukan dengan metode wawancara secara individual terhadap guru taman kanak-kanak terkait metode mengajar.

Subjek dalam penelitian ini adalah guru Taman Kanak-Kanak yang ada di Kelurahan Meruya Selatan. Jumlah subjek dalam penelitian ini sebanyak 8 orang yang terdiri dari 4 orang guru TK-A dan 4 orang guru TKB.

Alat ukur di dalam penelitian ini terdiri dari panduan wawancara yang disusun oleh peneliti berdasarkan metode mengajar yang sesuai dan tidak sesuai dikembangkan di dalam pendidikan masa awal anak-anak rekomendasi National Association for the Education of Young Children (NAEYC).

\section{HASIL DAN PEMBAHASAN}

Berdasarkan wawancara yang dilakukan terhadap 8 orang subjek penelitian, maka diperoleh hasil sebagai berikut :

1. Menciptakan komunitas yang peduli peserta didik.

a. Mempromosikan iklim yang positif untuk belajar.

Menurut guru, iklim yang positif untuk belajar adalah suasana yang menyenangkan.

Guru menumbuhkan susana yang menyenangkan untuk belajar tersebut 
dengan bercerita melalui gambar, pengalaman anak, atau pengalaman guru sendiri (TK A) dan permainan dan nyanyian (TK B).

Guru membantu anak-anak belajar bagaimana membangun hubungan yang positif dan konstruktif dengan orang dewasa dan anak-anak lainnya. Guru mendukung awal pertemanan anak-anak dan memberikan kesempatan bagi anakanak untuk belajar dari satu sama lain maupun orang dewasa.

b. Membina kelompok kohesif dan memenuhi kebutuhan individu.

Guru mengenal setiap anak dengan baik dan merancang kegiatan berdasarkan pengetahuan mereka tentang perbedaan kemampuan individual anak-anak, tingkat perkembangan, dan pendekatan untuk belajar.

Guru menggunakan berbagai strategi untuk membangun rasa kelompok sebagai komunitas yang kohesif.

Guru membawa budaya rumah dan bahasa masing-masing anak ke dalam budaya bersama sekolah sehingga anak-anak merasa diterima dan mendapatkan rasa memiliki, Kontribusi dari masing-masing keluarga dan budaya kelompok anak diakui dan dihargai oleh orang lain. Anak belajar untuk menghormati dan menghargai persamaan dan perbedaan antara orang-orang.

Menyadari nilai bekerja dan bermain bersama-sama, guru memberikan banyak kesempatan bagi anak-anak untuk bekerja di kelompok kecil, fleksibel di mana anak-anak secara informal membuat atau guru yang mengatur.

2. Mengajar untuk meningkatkan pengembangan dan belajar.

a. Lingkungan dan jadwal.
Guru merencanakan dan menyiapkan lingkungan belajar yang mendorong inisiatif anak-anak, eksplorasi aktif terhadap materi, keterlibatan berkelanjutan dengan anak-anak lain, orang dewasa, dan kegiatan. Dalam memilih bahan dan peralatan, guru mempertimbangkan tingkat perkembangan anak dan konteks sosial/budaya, misalnya lokasi geografis dari progran dan latar belakang anak-anak.

Guru mempertahankan lingkungan yang aman, sehat dan pengawasan hati-hati. Mereka mengantisipasi dan menghindari kecelakaan atau masalah sebelum itu terjadi. Guru menjaga keselamatan anak-anak, juga mendorong anakanak untuk melakukan apa yang mereka mampu lakukan untuk diri mereka sendiri. Guru mendukung mengambil risiko yang sesuai dengan usia anak-anak dalam batas yang aman.

b. Pengalaman belajar.

Guru merencanakan berbagai pengalaman belajar konkret dengan materi dan orang-orang yang relevan dengan pengalaman hidup anak-anak sendiri dan yang mendorong ketertarikan mereka, keterlibatan dalam pembelajaran, dan pengembangan konseptual.

Guru memberikan kesempatan bagi anak-anak untuk merencanakan dan memilih banyak dari kegiatan mereka sendiri dari antara berbagai bidang pembelajaran dan proyek yang mereka dapat, berdasarkan tujuan program dan informasi yang dikumpulkan tentang berbagai minat dan kemampuan anak-anak. Mengikuti ketertarikan mereka sendiri, anak-anak memilih dari antara berbagai kegiatan. 
c. Bahasa dan komunikasi.

Guru mendorong perkembangan keterampilan bahasa dan komunikasi anak-anak dengan berbicara dengan mereka sepanjang hari, berbicara dengan jelas dan mendengarkan tanggapan mereka, dan memberikan kesempatan bagi mereka untuk berbicara satu sama lain. Guru melibatkan anak-anak secara individu dan kelompok dalam percakapan tentang pengalaman nyata, proyek, dan peristiwa terkini; mereka mendorong anak-anak untuk menggambarkan produk atau ide-ide mereka, dan mereka merespon dengan penuh perhatian terhadap inisiatif verbal anak-anak.

d. Strategi pengajaran.

Guru mengamati dan berinteraksi dengan individu dan kelompokkelompok kecil dalam semua konteks (termasuk pengalaman belajar yang direncanakan guru dan dipilih anak) untuk memaksimalkan pengetahuan mereka tentang apa yang anak-anak dapat lakukan dan apa yang setiap anak mampu lakukan dengan dan tanpa bimbingan, atau bantuan lainnya.

Tidak menyadari berapa banyak anak-anak mampu belajar, guru tidak melibatkan mereka dalam dialog di mana mereka mengambil ide-ide anak-anak dengan serius, serta mereka tidak mendorong anak-anak untuk mengekspresikan ide-ide melalui mode representasi (non lisan) lainnya.

Guru meluaskan pemikiran dan pembelajaran anak dalam kegiatan yang diprakarsai anak dengan megajukan masalah, mengajukan pertanyaan, membuat saran, menambahkan kompleksitas tugas, dan memberikan informasi, materi, dan bantuan yang diperlukan untuk memungkinkan anak untuk mengkonsolidasikan pembelajaran dan pindah ke tingkat fungsi berikutnya.

e. Motivasi dan bimbingan.

Guru memfasilitasi pengembangan keterampilan sosial, kontrol diri, dan regulasi diri pada anak-anak dengan menggunakan teknik bimbingan positif, seperti modeling dan mendorong perilaku yang diharapkan, mengarahkan anak-anak kepada kegiatan yang lebih dapat diterima, menetapkan batas yang jelas, dan intervensi untuk menegakkan konsekuensi untuk sesuatu yang tidak dapat diterima, perilaku berbahaya. Harapan guru menghormati kapasitas perkembangan anak-anak. Guru yang sabar, menyadari bahwa tidak setiap pelanggaran kecil memerlukan respon.

3. Menyusun kurikulum yang sesuai.

a.Kurikulum terpadu.

Tujuan kurikulum menunjukkan pembelajaran di semua bidang perkembangan - fisik, sosial, emosional, bahasa, estetika, dan intelektual.

Isi kurikulum dari berbagai disiplin ilmu, seperti matematika, sains, atau studi sosial, terintegrasi melalui tema, proyek, permainan, dan pengalaman belajar lainnya, sehingga anak-anak mengembangkan pemahaman tentang konsep dan membuat koneksi antar disiplin ilmu.

b. Kontinum perkembangan dan pembelajaran.

Rencana kurikulum dirancang untuk membantu anak-anak mengeksplorasi dan memperoleh konsep-konsep kunci dan alat penyelidikan dari berbagai disiplin ilmu dengan cara yang dipahami dan dapat diakses untuk usia mereka. Guru memiliki pengetahuan tentang kontinum perkembangan dan 
pembelajaran bagi anak-anak prasekolah di setiap bidang konten.

c. Kurikulum yang koheren, efektif.

Guru fleksibel mengikuti rencana kurikulum yang ditentukan dengan memperhatikan konteks yang spesifik dan berubah-ubah.

d. Isi dan pendekatan kurikulum.

Guru menggunakan berbagai pendekatan dan memberikan kesempatan harian untuk mengembangkan keterampilan bahasa dan keaksaraan anak-anak melalui pengalaman yang berarti.

Guru menggunakan berbagai strategi untuk membantu anak-anak mengembangkan konsep dan keterampilan dalam matematika, sains, studi sosial, kesehatan, dan bidang konten lainnya melalui berbagai kegiatan yang berarti.

Anak-anak memiliki kesempatan sepanjang hari untuk bergerak bebas dan menggunakan otot-otot besar dalam kegiatan bergerak yang direncanakan.

Anak-anak memiliki kesempatan sepanjang hari untuk mengembangkan keterampilan motorik halus melalui kegiatan bermain.

Anak-anak memiliki kesempatan dan dukungan guru untuk menunjukkan dan melatih perkembangan keterampilan bantu diri.

Seni dan musik diberikan hanya jika waktu memungkinkan.

1. Menilai pembelajaran dan perkembangan anak-anak.

Guru menggunakan penilaian observasi terhadap kemajuan anak-anak, pemeriksaan sampel karya anak, dan dokumentasi perkembangan mereka dan belajar untuk merencanakan dan mengadaptasikan kurikulum untuk memenuhi kebutuhan perkembangan atau belajar individual anak-anak, mengidentifikasi anak-anak yang mungkin memiliki masalah belajar atau perkembangan, berkomunikasi dengan orangtua, dan mengevaluasi efektivitas program.

2. Hubungan timbal balik dengan orangtua. Komunikasi dengan orangtua terbatas. Guru berkomunikasi dengan orangtua hanya sekitar masalah.

3. Kebijakan program.

Guru memenuhi syarat untuk bekerja dengan anak prasekolah dan taman kanak-kanak sebagai hasil dari tingkat perguruan tinggi dalam persiapan pendidikan anak usia dini atau perkembangan anak. Guru terlibat dalam kegiatan pengembangan profesional berkelanjutan. Ukuran kelompok dan rasio guru untuk anak dibatasi untuk memungkinkan pemrograman individual dan sesuai dengan usia (TK A). Ukuran kelompok dan rasio guru untuk anak tidak memungkinkan pemrograman individual dan sesuai dengan usia (TK B).

Berdasarkan wawancara yang dilakukan terhadap 8 orang guru taman kanak-kanak di Kelurahan Meruya Selatan Jakarta Barat, diperoleh hasil bahwa guru taman kanak-kanak di Kelurahan Meruya Selatan sudah menunjukkan metode mengajar yang sesuai dikembangkan dalam program taman kanakkanak hampir pada semua komponen kecuali komponen strategi pembelajaran (menyikapi ide-ide yang disampaikan oleh anak-anak), isi dan pendekatan kurikulum (ekspresi estetika), hubungan timbal balik dengan orangtua, dan kebijakan program (rasio guru-anak).

Pada komponen strategi pengajaran (menyikapi ide-ide yang disampaikan oleh anak-anak), tidak menyadari berapa banyak anak-anak mampu belajar, guru tidak 
melibatkan mereka dalam dialog di mana mereka mengambil ide-ide anak-anak dengan serius, serta mereka tidak mendorong anakanak untuk mengekspresikan ide-ide melalui mode representasi (non lisan) lainnya. Ketika anak-anak mengekspresikan ide-idenya, anakanak sebetulnya sedang belajar mempertajam konsep dan pemahaman mereka sendiri dan membantu guru memahami apa yang anakanak ketahui dan pikirkan. Dengan guru tidak menyediakan waktu dan dukungan untuk mengembangkan konsep dan keterampilan artinya guru meremehkan kemampuan intelektual anak. Anak kehilangan kesempatan untuk merencanakan, memikirkan, merenungkan dan meninjau kembali pengalaman mereka sendiri melalui diskusi, pemodelan, pelatihan, dan strategi lainnya.

Pada komponen isi dan pendekatan kurikulum (ekspresi estetika), seni dan musik diberikan hanya jika waktu memungkinkan. Pengembangan seni pada anak TK bertujuan untuk menawarkan sejumlah pengalaman yang bermanfaat untuk mengasah sensitivitas anak, serta menstimulus ide-ide kreatif dan imajinatif dari anak-anak. Melalui seni seorang anak akan dilatih kehalusan budi karena seni mengolah kepekaan anak terhadap alam sekitar dan hal-hal yang berkaitan dengan keindahan (Ki Hajar Dewantoro dalam Kamaril W.S. 1998 dalam Widia Pekerti, 2005 dalam www.kompasiana.com). Ada 7 fungsi dari pengembangan seni (Direktorat Pembinaan Taman Kanak-Kanak dan Sekolah Dasar, 2007:17), yaitu :

1. Melatih ketelitian dan kerapian anak.

2. Mengembangkan fantasi dan kreativitas anak.

3. Melatih motorik halus anak.

4. Memupuk pengamatan, pendengaran, dan daya cipta anak.

5. Mengembangkan perasaan estetika, dan menghargai hasil karya anak lain.
6. Mengembangkan imajinasi anak.

7. Mengenalkan cara mengekspresikan diri dengan menggunakan teknik yang telah dikuasai oleh anak.

Untuk itu pendidikan TK diharapkan memberi kesempatan sepenuhnya untuk memenuhi kebutuhan berekspresi dengan berbagai cara dan media kreatif (alat untuk berkreasi), seperti kegiatan-kegiatan dengan menggunakan kertas, pensil berwarna, krayon, tanah liat, bahan alam, bahan bekas dan lainnya. Di dalam kegiatan pengembangan seni terdapat bermacam-macam kegiatan yaitu seni corak/gambar, seni lukis, seni bentuk, seni musik, seni suara dan seni tari.

Pada komponen hubungan timbal balik dengan orangtua, komunikasi guru dengan orangtua terbatas dan guru berkomunikasi dengan orangtua hanya sekitar masalah. Keterlibatan orangtua dalam pendidikan anak merupakan berbagai bentuk aktivitas yang dilakukan oleh orang tua melalui kerjasama dengan guru baik di rumah maupun di sekolah, guna memaksimalkan perkembangan dan pendidikan anak di sekolah demi keuntungan mereka, anak dan program sekolah. Henderson dkk. (dalam Ferara \& Ferara, 2005 dalam Diadha) bahwa keterlibatan orang tua merupakan hal yang sangat penting untuk mendukung belajar anak, baik di sekolah formal maupun di kursus belajar. Adapun manfaat yang dapat diraih anak dengan adanya keterlibatan orang tua dalam pendidikan akan mampu meningkatkan kehadiran mereka di sekolah, sikap dan perilaku mereka (Hornby, 2011 hlm. 2; Menheree \& Hooge, 2010 dalam Diadha). Disamping itu, keterlibatan orang tua juga akan dapat meningkatkan prestasi dan kepribadian mereka (Zedan, 2011; Menheree \& Hooge, 2010 dalam Diadha). Orang tua juga akan mendapat keuntungan tersendiri dari keterlibatan mereka dalam pendidikan anak, diantaranya adalah kepercayaan diri dan kepuasan dalam mengasuh anak mereka (Hornby, 2011, hlm. 2 dalam Diadha), menambah wawasan dan pengalaman 
mengasuh serta mendidik anak (Powel, 2000 dalam Diadha), serta meningkatkan keterampilan mereka dalam mengasuh anak (Epstein, Sander, Simon, Salinas, Jansorn, dan Voorhis, 2002, hlm. 16 dalam Diadha). Selain itu, akan terwujud suasana sekolah yang lebih baik, perbaikan pada perilaku dan sikap guru serta memperbaiki hubungan antara orang tua dan guru (Hornby, 2011, hlm. 2 dalam Diadha). Keterlibatan orang tua juga akan mampu membantu meringankan tugas guru di sekolah (Epstein dkk., 2002, hlm. 17 dalam Diadha).

Pada komponen kebijakan program (rasio guru-anak), ukuran kelompok dan rasio guru untuk anak tidak memungkinkan pemrograman individual dan sesuai dengan usia. Untuk PAUD dengan anak didik berusia 4-6 Tahun, yakni untuk jenjang Kelompok Bermain (KB) dan Taman Kanak-Kanak (TK), maka rasio guru dan anak maksimal 1:15. Artinya, satu orang guru KB ataupun TK sebaiknya tidak melayani lebih dari 15 orang anak didik. Peraturan tentang Standar PAUD ini disusun untuk menjamin kualitas dan mutu PAUD (Permendikbud nomor 137 tahun 2014).

Bila dicermati lebih jauh, saat ini anakanak di TK, khususnya TK-B, sudah cenderung diajari materi baca, tulis, dan hitung (calistung) tujuannya supaya lolos seleksi masuk SD. Hal ini disampaikan sendiri oleh guru taman kanak-kanak di Kelurahan Meruya Selatan Jakarta Barat. Tentu saja hal tersebut sama sekali tidak sesuai dengan tujuan semula taman kanak-kanak didirikan. Tujuan Pendidikan TK : (a) Membantu pertumbuhan dan perkembangan jasmani dan rohani agar anak memiliki kesiapan dalam memasuki pendidikan lebih lanjut (Pasal 1.14 UndangUndang Republik Indonesia Nomor 20 Tahun 2003); (b) Mengembangkan kepribadian dan potensi diri sesuai dengan tahap perkembangan peserta didik (Penjelasan Pasal 28 ayat 3 Undang-Undang Republik Indonesia Nomor 23 Tahun 2003); (c) Membantu meletakkan dasar kearah perkembangan sikap, pengetahuan, keterampilan, dan daya cipta yang diperlukan oleh anak didik dalam menyesuaikan diri dengan lingkungannya dan untuk pertumbuhan serta perkembangan selanjutnya (Pasal 3 Peraturan Pemerintah Republik Indonesia Nomor 27 Tahun 1990). Pengenalan membaca, menulis dan berhitung (calistung) dilakukan melalui pendekatan yang sesuai dengan tahap perkembangan anak. Oleh karena itu pendidikan di TK tidak diperkenankan mengajarkan materi calistung secara langsung sebagai pembelajaran sendirisendiri (fragmented) kepada anak-anak. Konteks pembelajaran calistung di TK hendaknya dilakukan dalam kerangka pengembangan seluruh aspek tumbuh kembang anak, dilakukan melalui pendekatan bermain dan disesuaikan dengan tugas perkembangan anak. Menciptakan lingkungan yang kaya dengan "keaksaraan" akan lebih memacu kesiapan anak untuk memulai kegiatan calistung.

\section{SIMPULAN}

Berdasarkan wawancara yang dilakukan terhadap 8 orang guru taman kanak-kanak di Kelurahan Meruya Selatan Jakarta Barat, diperoleh hasil bahwa guru taman kanak-kanak di Kelurahan Meruya Selatan Jakarta sudah menunjukkan metode mengajar yang sesuai dikembangkan dalam program taman kanakkanak hampir pada semua komponen kecuali komponen strategi pengajaran (menyikapi ideide yang disampaikan oleh anak-anak), isi dan pendekatan kurikulum (ekspresi estetika), hubungan timbal balik dengan orangtua, dan kebijakan program (rasio guru-anak).

\section{Saran}

\section{Saran Teoritis}

Perlu dilakukan pengabdian pada masyarakat pada guru taman kanakkanak di Kelurahan Meruya Selatan 
Jakarta Barat tentang bagaimana pengembangan seni pada anak TK.

\section{Saran Praktis}

a. Bagi guru agar menanggapi ide-ide anak-anak dengan serius dan mendorong anak-anak untuk mengekspresikan ide-ide melalui mode representasi (non lisan) lainnya dalam rangka memberikan kesempatan bagi anak-anak untuk mengembangkan konsep dan keterampilan.

b. Bagi guru agar memberikan kesempatan bagi anak-anak untuk ekspresi estetika dan apresiasi melalui seni dan musik seperti permainan drama, musik, dan tari, berbagai media seni, seperti spidol, krayon, cat, dan clay.

c. Bagi guru agar bekerja dalam kemitraan dengan orangtua, berkomunikasi secara berkala untuk membangun saling pengertian dan memastikan bahwa kebutuhan pembelajaran dan perkembangan anak-anak terpenuhi.

d. Bagi guru agar membatasi rasio guru-anak untuk memungkinkan pemrograman individual dan sesuai dengan usia.

e. Bagi guru agar mengenalkan membaca, menulis, dan berhitung melalui pendekatan yang sesuai dengan tahap perkembangan anak, melalui pendekatan bermain dan menciptakan lingkungan yang kaya dengan "keaksaraan".

\section{DAFTAR PUSTAKA}

Diadha, R. 2015. Keterlibatan Orang Tua Dalam Pendidikan Anak Usia Dini Di Taman Kanak-Kanak. Edusentris,
Jurnal Ilmu Pendidikan dan Pengajaran, Vol. 2 No.1.

National Association for the Education of Young Children. 1997. Developmentally Appropriate Practice in Early Childhood Washington, D.C.: Programs Revised Edition.

Papalia, Diane E., Sally Wendkos Olds, Ruth Duskin Feldman. Human Development Perkembangan Manusia Edisi 10 Buku 1. Terjemahan oleh Brian Marswendy. 2009. Jakarta : Salemba Humanika.

Santrock, J., W. Life-Span Development Perkembangan Masa Hidup Edisi Kelima Jilid 1. Terjemahan oleh Juda Damanik, Achmad Chusairi. 2002. Jakarta : Erlangga.

Sen, A; Partelow, L., \& Miller, D.C. (2005). Comparative indicators of education in the United States and other G8 countries : 2004 (NCES 2005-021). Washington, DC : National Center for Education Statistics.

Artikel : Tujuan dan Prinsip Pendidikan TK. 12 Juni 2009. Melalui : https://tunas63.wordpress.com/2009/06/ 12/artikel-tujuan-dan-prinsippendidikan-tk-2/ (28/04/16).

Dasar Penyelenggaraan Pendidikan Taman Kanak-Kanak. 07.11. Melalui http://pkgpaudjatinangor.blogspot.co.id/ 2013/04/dasar-penyelenggaraanpendidikan-taman.html (06/11/15).

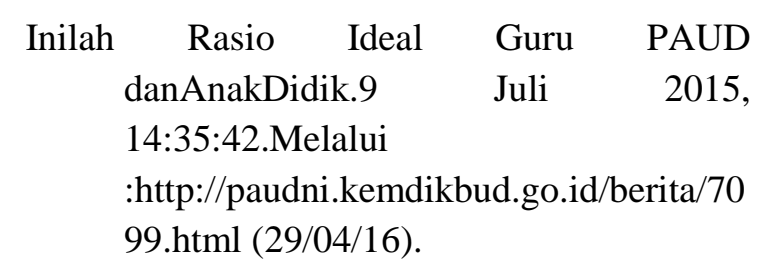


Mulai 2016, Wajib TK Sebelum Masuk SD. Jumat, 19 Juni 2015, 04:52:00. Melalui : http://www.jpnn.com/read/2015/06/19/3 10452/Mulai-2016,-Wajib-TK-SebelumMasuk-SD- (06/11/15).

PendidikanSeniuntuk Taman Kanak-kanak. 12 November 2010 03:32:57. Melalui :http://www.kompasiana.com/ariesrohm adi/pendidikan-seni-untuk-taman-kanakkanak_55004193a333114a73510472 (29/04/2016).

Pengembangan Seni Di Taman KanakKanak.Minggu, $\quad 30 \quad$ oktober 2011.Melalui :http://kunt34.blogspot.co.id/2011/10/pe ngembangan-seni-di-taman-kanakkanak.html (29/04/16).

Pengembangan Seni di Taman Kanak-Kanak (TK). 2016. Melalui :http://membumikanpendidikan.blogspot.co.id/2015/03/peng embangan-seni-di-taman-kanakkanak.html (29/04/16).

Pengertian TK Taman Kanak-Kanak. 2014. Melalui : $\quad$ http://skripsitarbiyahpai.blogspot.co.id/2015/01/peng ertian-tk-taman-kanak-kanak.html (06/11/15).

Taman Kanak. September 2011. Melalui https://kylua.wordpress.com/pendidika/t aman-kanak/ (28/04/16). 